\title{
Cucumber mosaic virus Establishes Systemic Infection at Increased Temperature Following Viral Entrance Into the Phloem Pathway of Tetragonia expansa
}

\author{
Takashi Kobori, Takeshi Osaki, and Satoshi T. Ohki
}

Graduate School of Agriculture and Biological Sciences, Osaka Prefecture University, Sakai, Osaka 599-8531, Japan. Current address for T. Kobori: Kyoto Prefectural Institute of Agricultural Biotechnology, Seika-cho, Kyoto 619-0244, Japan. Accepted for publication 3 June 2003.

\begin{abstract}
Kobori, T., Osaki, T., and Ohki, S. T. 2003. Cucumber mosaic virus establishes systemic infection at increased temperature following viral entrance into the phloem pathway of Tetragonia expansa. Phytopathology 93:1445-1451.

A potential regulatory site for Cucumber mosaic virus (CMV, pepo strain) movement necessary to establish systemic infection was identified through immunological and hybridization studies on Tetragonia expansa, which was systemically infected by $\mathrm{CMV}$ at $36^{\circ} \mathrm{C}$ but not at $24^{\circ} \mathrm{C}$. In inoculated leaves, cell-to-cell movement of CMV was enhanced at $36^{\circ} \mathrm{C}$

both 36 and $24^{\circ} \mathrm{C}$. CMV was detected in the petioles of inoculated leaves, stems, and petioles of uninoculated upper leaves at $36^{\circ} \mathrm{C}$, whereas CMV was detected only in the petioles of inoculated leaves and in stems at $24^{\circ} \mathrm{C}$. CMV moved into the phloem and was transported to the stem within $24 \mathrm{~h}$ postinoculation (hpi) at $36^{\circ} \mathrm{C}$. However, it did not accumulate in the petioles of the upper leaves until $36 \mathrm{hpi}$. In petioles of inoculated leaves at $24^{\circ} \mathrm{C}, \mathrm{CMV}$ was detected in the external phloem but not in the internal phloem. From these results, we conclude that systemic infection is established after viral entrance into the phloem pathway in $T$. expansa at $36^{\circ} \mathrm{C}$.
\end{abstract} compared with that observed at $24^{\circ} \mathrm{C}$. CMV was distributed in the phloem cells of minor veins as well as epidermal and mesophyll cells at
Additional keywords: long-distance virus movement, resistance mechanism.
Systemic infection of plant viruses depends on several processes. Viruses replicate in an initially infected cell and then move to adjacent cells through plasmodesmata (cell-to-cell movement). Moving through mesophyll cells, the viruses enter sieve elements through bundle sheath cells, phloem parenchyma cells, and/or companion cells and then are transported to other organs and tissues through the phloem (long-distance movement). These processes have, to date, been extensively reviewed $(4,13,21,22,26)$.

Cell-to-cell or long-distance movement of viruses is a key factor in determining viral host range, and the inhibition of either movement is a common resistance mechanism to viral infection. Restriction of long-distance movement may be caused by the inhibition of loading into the phloem, transportation through the phloem, or unloading from the phloem to nonvascular tissues. The restriction of viral movement into phloem was shown at bundle sheath cell-phloem cell interfaces in some cases: Cucumber mosaic virus (CMV) in Cucumis figarei (20), Cowpea chlorotic mottle virus in a resistant soybean line (14), Tomato aspermy virus in cucumber (32), and CMV in a transgenic tobacco exhibiting replicase-mediated resistance (38). The restriction after phloem entry was reported for Tobacco etch virus in a resistant tobacco line (25), Pepper mottle virus (PepMoV) in a resistant pepper (15), CMV in a resistant pepper (11), Carnation mottle virus in Chenopodium quinoa under growth chamber conditions (12), Tobacco mosaic virus (TMV) lacking its coat protein (CP) (10), and Turnip vein clearing virus in tobacco treated with cadmium at a nontoxic concentration (6).

CMV is a $30-n m$ icosahedral plant virus consisting of singlestranded, positive-sense RNA and has three genomic RNAs. RNA

Corresponding author: S. T. Ohki; E-mail address: ohki@plant.osakafu-u.ac.jp

Publication no. P-2003-0919-01R

(c) 2003 The American Phytopathological Society
3 has two open reading frames that encode 3 a protein and $\mathrm{CP}$. The 3 a protein is essential for cell-to-cell movement and is referred to as the movement protein $(7,18,37)$. CP is also required for cell-tocell movement $(2,3,28)$. Both $3 \mathrm{a}$ protein and $\mathrm{CP}$ are necessary for long-distance movement $(18,31)$. The $2 \mathrm{~b}$ protein, encoded by RNA 2, also is reported to affect systemic movement $(9,27)$.

Tetragonia expansa, family Aizoaceae, shows only local infection at $24^{\circ} \mathrm{C}$, but is systemically infected at $36^{\circ} \mathrm{C}$, with the pepo strain of CMV. The systemic movement under high temperature was determined by one amino acid at position 129 in CP, which is encoded by CMV RNA 3 (19). However, regulatory sites for CMV movement necessary to establish systemic infection have not been determined. In this paper, we report that the systemic accumulation of pepo-CMV is restricted after entry into the phloem at $24^{\circ} \mathrm{C}$ in $T$. expansa; possibly caused by the inhibition of viral transport from the external phloem to the internal phloem.

\section{MATERIALS AND METHODS}

Plants, CMV strains, and CMV inoculation. T. expansa was grown in growth chambers (NK Systems, Osaka, Japan) with a 16-h light/8-h dark cycle. T. expansa plants grown to the five- to seven-leaf-stage were used for inoculation and incubated at 24 or $36^{\circ} \mathrm{C}$. Pepo-CMV was used in this study (23). CMV was propagated in tobacco (Nicotiana tabacum cv. Xanthi) and purified as described previously (30). The one or two largest leaves of the $T$. expansa plants were mechanically inoculated with purified virus at a concentration of $100 \mu \mathrm{g} / \mathrm{ml}$.

Tissue fixation, embedding, and sectioning. Tissue fixation procedures were performed as described by van Lent and Verduin (36) with minor modifications. Leaf samples $(1 \times 10 \mathrm{~mm})$ that contained chlorotic tissue from inoculated leaves and petioles ( $5 \mathrm{~mm}$ long) were obtained at 5 days postinoculation (dpi). The tissue samples were fixed under vacuum in $1 \%$ (wt/vol) glutaralde- 
hyde and $4 \%$ (wt/vol) paraformaldehyde in $0.1 \mathrm{M}$ phosphate

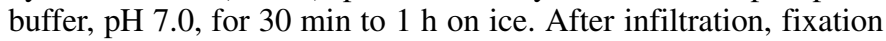
was allowed to proceed for $12 \mathrm{~h}$ at $4^{\circ} \mathrm{C}$. The samples were washed six times for $10 \mathrm{~min}$ in buffer and dehydrated in a graded series of ethanol $(30,50,70$, and $90 \%$ for 20 min each under vacuum; and $100 \%$ twice for $20 \mathrm{~min}$ ) at room temperature. The ethanol was replaced with LR White Resin (London Resin, Reading, UK) by incubating in a $1: 1$ mixture of ethanol/LR White for $1 \mathrm{~h}$ at room temperature and then pure LR White for $1 \mathrm{~h}$ at room temperature followed by an overnight incubation at $4^{\circ} \mathrm{C}$ in fresh LR White. The tissue samples were transferred to BEEM Conical Tip capsules (Better Equipment for Electron Microscopy Inc., New York), and the resin was polymerized for 16 to $24 \mathrm{~h}$ at $55^{\circ} \mathrm{C}$. Semithin sections were cut with glass knives on a Leica UCT ultramicrotome (Leica Microsystems AG, Vienna, Austria). The sections were transferred with tweezers onto drops of distilled water and dried onto aminopropylsilane-coated glass slides (Matsunami, Osaka, Japan).
Immuno-histochemistry. Procedures for immuno-histochemistry were as described previously (36). Specifically, the sections were incubated for $30 \mathrm{~min}$ at room temperature in $1 \%$ bovine serum albumin (BSA) in phosphate-buffered saline (PBS: $8.1 \mathrm{mM}$ $\mathrm{Na}_{2} \mathrm{HPO}_{4}, 1.5 \mathrm{mM} \mathrm{KH} \mathrm{PO}_{4}, 0.137 \mathrm{M} \mathrm{NaCl}$, and $2.7 \mathrm{mM} \mathrm{KCl}$ ), $\mathrm{pH} 7.4$, in a vertical staining jar. Primary antibody solution (1:200 dilution of mouse monoclonal antiserum prepared against pepoCMV CP in PBS containing $0.05 \%$ Tween 20 and $1 \%$ BSA [PBST-BSA]) was dropped onto the sections, and the sections were incubated horizontally overnight at $4^{\circ} \mathrm{C}$. After washing the slides three times (10 min each) in PBST, secondary antibody solution (1:40 dilution of immunogold conjugated LM goat antimouse [British Biocell, Cardiff, UK] in PBST-BSA) was dropped onto sections, and the sections were incubated for $90 \mathrm{~min}$ at room temperature. The slides were washed three times as described previously, fixed for $15 \mathrm{~min}$ in $1 \%(\mathrm{wt} / \mathrm{vol})$ glutaraldehyde in PBS, and washed twice (10 min each) in distilled water. Silver enhancement of gold labeling was conducted by addition of silver

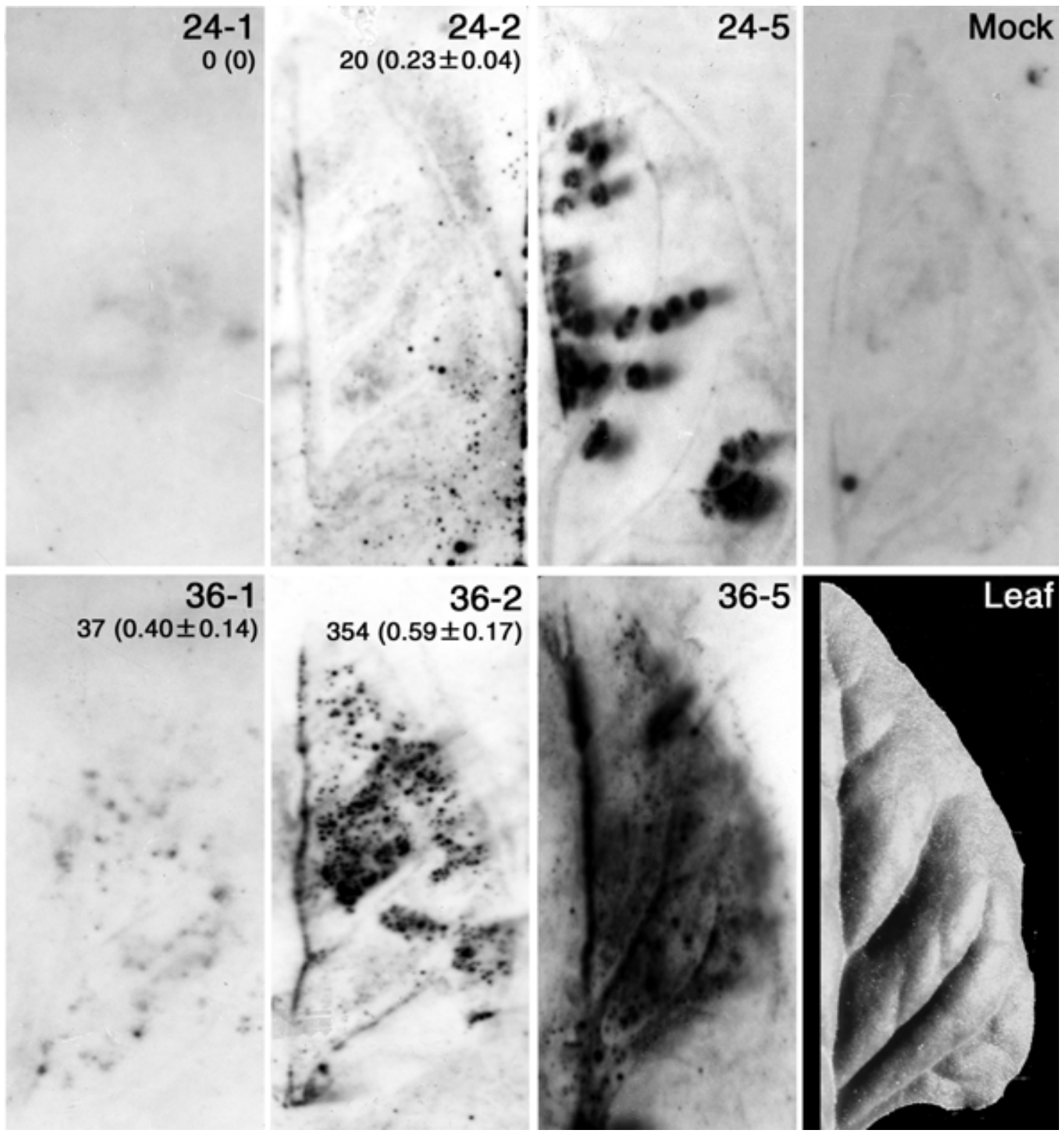

Fig. 1. Leaf press-blot analysis of Cucumber mosaic virus (CMV)-inoculated leaves from Tetragonia expansa incubated at $24^{\circ} \mathrm{C}(24)$ or $36^{\circ} \mathrm{C}(36)$ at 1,2 , and 5 days postinoculation (dpi) (indicated by 1,2, and 5, respectively). The right half of the inoculated leaves (Leaf) was pressed onto nylon membranes. Viral RNA was probed with a digoxigenin-labeled RNA complementary to the $3^{\prime}$ common sequence of CMV positive-sense RNAs. No signal was detected in the mock-inoculated leaf (Mock). These two series (24 and 36) of panels are from the same membrane. Number and size (millimeter with standard error) of the infection foci at 1 and 2 dpi are also indicated. 
enhancing solution (IntenSEM; Amersham Biosciences, Uppsala, Sweden) to each section followed by incubation for 8 to $15 \mathrm{~min}$ at room temperature. The sections were viewed and photographed with a microscope (Olympus BX-20; Olympus, Tokyo).

Leaf press-blotting and dot blotting. Leaf press-blotting was performed as described by Uchiba et al. (34) with minor modification. The lower sides of the leaves sampled at 1,2, and 5 dpi were mildly abraded with celite using a toothbrush. After treating in distilled water, the leaves were incubated in W5 solution (29) containing $0.7 \%$ cellulase and $0.25 \%$ macerozyme (Yakult Pharmaceutical Inc., Tokyo) for $2 \mathrm{~h}$ at room temperature. The leaves were transferred onto nylon membrane $\left(H y b o n d ~ N^{+}\right.$; Amersham Bio- sciences) with the treated side down and blotted for 30 min with a vacuum gel dryer (Rapidry-mini; ATTO, Tokyo) at room temperature. The membrane was rinsed in $2 \times \mathrm{SSC}(1 \times \mathrm{SSC}$ is $0.15 \mathrm{M}$ $\mathrm{NaCl}$ plus $0.015 \mathrm{M}$ sodium citrate), $0.1 \%$ sodium dodecyl sulfate, dried at room temperature, and baked at $80^{\circ} \mathrm{C}$ for $2 \mathrm{~h}$.

For dot blotting, total RNA was extracted from the leaves as described previously (23). The total RNA extracts $(5 \mu \mathrm{l})$ were applied onto a nylon membrane and the membrane was baked at $80^{\circ} \mathrm{C}$ for $2 \mathrm{~h}$. Digoxigenin-labeled T7 RNA polymerase-derived transcripts from pCP3TS503 (24), complementary to the $3^{\prime}$ common sequences of CMV RNA, were used as a probe to detect plus-sense CMV RNAs in leaf press-blotting and dot blotting.
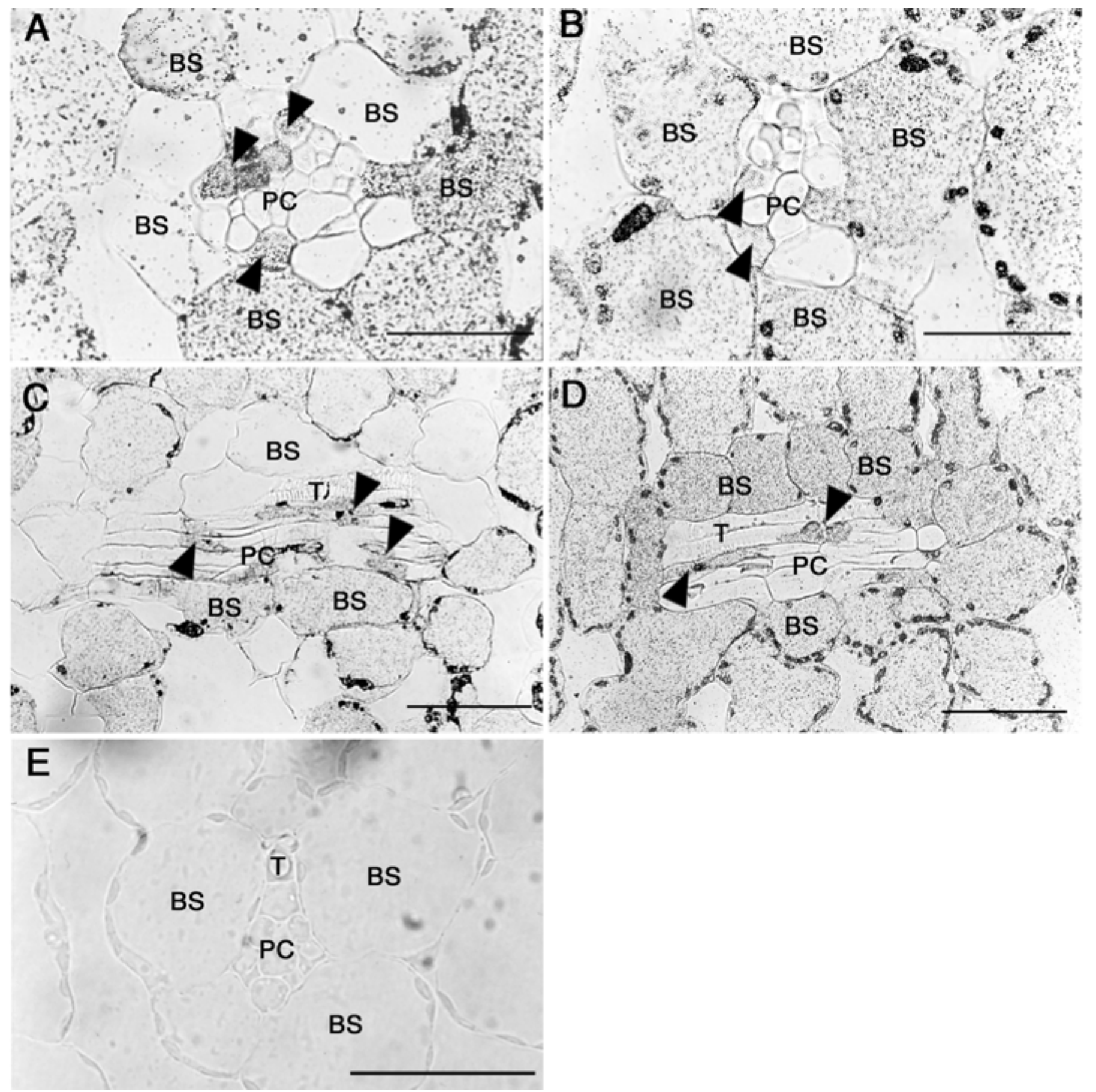

Fig. 2. Immuno-histochemical analysis of $\mathbf{A}$ and $\mathbf{B}$, transverse and $\mathbf{C}$ and $\mathbf{D}$, longitudinal sections of inoculated leaves containing fourth- or fifth-order minor veins of Tetragonia expansa grown at 24 and $36^{\circ} \mathrm{C}$. Samples were excised at 5 days postinoculation and immuno-stained with an antibody against Cucumber mosaic virus (CMV) coat protein. Bundle sheath cells (BS) and phloem cells (PC) including phloem parenchyma cells, companion cells, and sieve elements at $\mathbf{A}$ and $\mathbf{C}, 36^{\circ} \mathrm{C}$ and $\mathbf{B}$ and $\mathbf{D}, 24^{\circ} \mathrm{C}$ are indicated. $\mathbf{E}$, A vein from healthy control. Arrowheads show phloem cells containing CMV. T $=x y l e m$ tracheary elements. Bars $=20 \mu \mathrm{m}$. 
Hybridization and detection were performed as described previously (19).

Reverse transcription-polymerase chain reaction. Total RNA (500 ng) extracts from $T$. expansa tissues were reverse-transcribed to single-stranded cDNA using the primer P3R123Bam $\left(5^{\prime}-\right.$ CCGGATCCTGGTCTCCTTTTGGAGGCCC-3') complementary to the $3^{\prime}$ common ends of CMV. About $500 \mathrm{bp}$ of a pepo-CMV CP gene fragment was amplified using the primers pepoCPF $\left(5^{\prime}\right.$ CCTCTAGACTTCTCCGCGAGATTGCG-3': positions 1,166 to 1,183) and P3CPR3/4 (5'-CCGAGCTCTCAAGCTTGAACTCCAGATGCA-3': positions 1,724 to 1,742 ). In the polymerase chain reaction (PCR), 20 cycles of amplification were performed under the following conditions: denaturation at $92^{\circ} \mathrm{C}$ for $1 \mathrm{~min}$, annealing at $60^{\circ} \mathrm{C}$ for $1 \mathrm{~min}$, and extension at $72^{\circ} \mathrm{C}$ for $1 \mathrm{~min}$. The products were electrophoresed through $1 \%$ agarose gel and stained with ethidium bromide. The stained gels were viewed and photographed with an ATTO Densitograph AE-6920M (ATTO, Tokyo).

\section{RESULTS}

Cell-to-cell movement in the inoculated leaves at 36 or $24^{\circ} \mathrm{C}$. Our previous experiments showed that, in $T$. expansa grown at $36^{\circ} \mathrm{C}$, pepo-CMV induced localized yellow spots on inoculated leaves by 2 to 3 dpi and systemic chlorotic spots and ringspots by 5 dpi, but only localized chlorotic spots on inoculated leaves of plants grown at $24^{\circ} \mathrm{C}$ by 3 to $5 \mathrm{dpi}$ (19). To compare local spread of $\mathrm{CMV}$ in the inoculated leaves at $24^{\circ} \mathrm{C}$ with that at $36^{\circ} \mathrm{C}$, we probed leaf press-blots obtained at 1,2 , and 5 dpi, respectively. CMV RNA signal was detected from tissue grown at $36^{\circ} \mathrm{C}$ as spots at $1 \mathrm{dpi}$, elongated regions associated with veins at $2 \mathrm{dpi}$, and massive coverage distributed throughout the leaf at 5 dpi (Fig. 1, 36-1, 36-2, and 36-5). In contrast, CMV RNA only was detected localized within infection loci by 5 dpi at $24^{\circ} \mathrm{C}$ (Fig. 1, 24-1, 24-2, and 24-5). Less RNA was detected at $24^{\circ} \mathrm{C}$ than at $36^{\circ} \mathrm{C}$ (Fig. 1). These results demonstrated that the cell-to-cell movement was facilitated at $36^{\circ} \mathrm{C}$ versus $24^{\circ} \mathrm{C}$.

CMV entry into phloem at 24 and $36^{\circ} \mathrm{C}$. Phloem entry in the inoculated leaves is a likely requirement for the establishment of systemic infection. Using immuno-histochemical methods, we examined whether CMV entered the phloem cells at $24^{\circ} \mathrm{C}$ by observing tissues from within lesions on the inoculated leaves at 24 and $36^{\circ} \mathrm{C}$. CMV antigenic signal was detected in epidermal cells, palisade and spongy mesophyll cells, and bundle sheath cells in fourth- or fifth-order veins (minor veins [8]) at both 24 and $36^{\circ} \mathrm{C}$. Vascular parenchyma cells and companion cells around sieve elements were indistinguishable by our method of observation (Fig. 2E; 22), and thus, we defined vascular parenchyma cells, companion cells, and sieve elements as phloem cells in this study. CMV was detected in the phloem cells of all the minor veins in the inoculated leaves from plants grown at $36^{\circ} \mathrm{C}$ (Fig. $2 \mathrm{~A}$ and $\mathrm{C}$; Table 1). The virus was also detected in the phloem cells of

TABLE 1. Cucumber mosaic virus (CMV) accumulation in different cell types in typical vascular bundles of Tetragonia expansa leaves from plants inoculated with $\mathrm{CMV}$ and grown at 24 or $36^{\circ} \mathrm{C}^{\mathrm{a}}$

\begin{tabular}{lccc}
\hline & $\begin{array}{c}\text { Number of veins ana- } \\
\text { lyzed (sampled tissue) }\end{array}$ & \multicolumn{2}{c}{ Number of vascular bundles (\%) } \\
\cline { 4 - 5 } Temperature & $10(8)$ & $10(100)$ & $7(70)$ \\
\hline $24^{\circ} \mathrm{C}$ & $14(10)$ & $14(100)$ & $14(100)$ \\
$36^{\circ} \mathrm{C}$ & &
\end{tabular}

a Data were based on immuno-histochemical detection of CMV coat protein around and within fourth- and fifth-order veins in semithin cross sections of the inoculated leaves. At 5 days postinoculation, tissues containing chlorotic spots were randomly sampled.

b Veins containing infected bundle sheath (BS) cells.

c Veins containing infected phloem cells, i.e., phloem parenchyma or companion cells. most of the minor veins from plants grown at $24^{\circ} \mathrm{C}$ (Fig. $2 \mathrm{~B}$ and $\mathrm{D}$; Table 1). These observations indicated that $\mathrm{CMV}$ entered the phloem tissues of the inoculated leaves from plants grown at $24^{\circ} \mathrm{C}$ as well as those grown at $36^{\circ} \mathrm{C}$, although CMV did not accumulate in systemic tissue from plants grown at $24^{\circ} \mathrm{C}$. Whether CMV invaded sieve elements or not remains unclear by the observations.

We then examined CMV accumulation in the petioles of the inoculated leaves, stems, and the petioles of the upper leaves from plants grown at $24^{\circ} \mathrm{C}$ by tissue printing and northern blotting. The upper leaves analyzed were the second leaf above the inoculated leaf. The stems were the internodes between the inoculated leaf and the upper leaf. No viral RNA signal was detected in these organs (data not shown), and therefore, we used reverse transcription (RT)-PCR for the tissues harvested at 5 dpi. CMV CP gene fragments were detected from the samples taken from the petioles of the inoculated leaves, stems, and the petioles of the upper leaves of plants grown at $36^{\circ} \mathrm{C}$ (Fig. 3B, lane 36). In contrast, RT$\mathrm{PCR}$ revealed that $\mathrm{CMV}$ was present in the petioles of the inoculated leaves and the stems, but not in detectable amounts in the petioles of the upper leaves of plants grown at $24^{\circ} \mathrm{C}$ (Fig. 3B, lane 24). These findings show that CMV reached the stems but did not accumulate in the petioles of the upper leaves of plants grown at $24^{\circ} \mathrm{C}$.

Is Incubation at $36^{\circ} \mathrm{C}$ necessary for $\mathrm{CMV}$ to establish systemic infection? We determined the incubation period for CMV to be transported from the inoculated tissues to the stem in plants grown at $36^{\circ} \mathrm{C}$. Inoculated leaves and petioles of plants incubated at $36^{\circ} \mathrm{C}$ were detached from their stems at $0,6,12,24,36,48$, or $72 \mathrm{~h}$ postinoculation (hpi); CMV RNA accumulation in the second upper leaves was analyzed by dot blotting at $8 \mathrm{dpi}$. No signal was detected in the upper leaves of the plants in which the inoculated leaves were detached at 0 to $12 \mathrm{hpi}$. In contrast, signal was detected in the plants in which leaves were detached at and after 24 hpi (Fig. 4A). These results indicated that CMV moved into the phloem of the inoculated leaves and was transported to the stem by $24 \mathrm{hpi}$ at $36^{\circ} \mathrm{C}$.

We then ascertained the required incubation period at $36^{\circ} \mathrm{C}$ for CMV to establish systemic infection in T. expansa. CMV-inoculated plants incubated at $36^{\circ} \mathrm{C}$ were moved to another growth chamber at $24^{\circ} \mathrm{C}$ at $0,6,12,24,36,48$, or $72 \mathrm{hpi}$ and were incubated until $8 \mathrm{dpi}$; the upper leaves were then assayed for CMV RNA by dot blot. CMV was not detected in the upper leaves of the plants moved to $24^{\circ} \mathrm{C}$ by $24 \mathrm{hpi}$. On the other hand, CMV was detected in the upper leaves of plants moved to $24^{\circ} \mathrm{C}$ at and after 36 hpi (Fig. 4B). These results indicated that CMV required $36 \mathrm{~h}$ at $36^{\circ} \mathrm{C}$ to establish a systemic infection even in plants placed back at $24^{\circ} \mathrm{C}$.

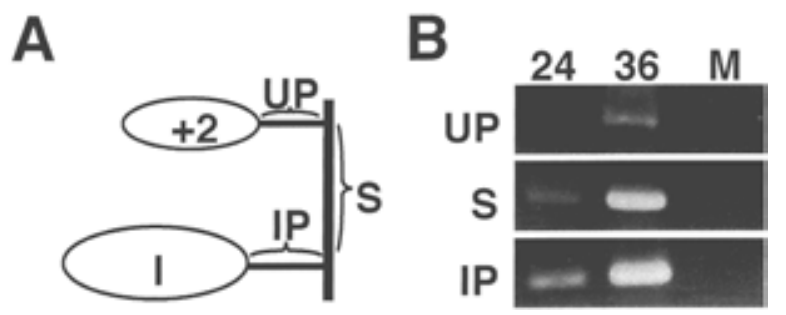

Fig. 3. Detection of Cucumber mosaic virus (CMV) RNA by reverse transcription-polymerase chain reaction (RT-PCR) in $\mathbf{A}$, the petioles of inoculated leaves (IP), stem ( $\mathrm{S}$, internode between the inoculated and upper leaves), and the petioles of the second systemic leaves (UP) of Tetragonia expansa inoculated with CMV and grown at $24 \mathrm{C}$ or $36^{\circ} \mathrm{C}$ for 5 days postinoculation. B, Total RNA (500 ng) extracted from IP, S, or UP was reverse-transcribed using primers that would amplify the CMV coat protein gene fragment, which is approximately $500 \mathrm{bp}$ long. RT-PCR products were electrophoresed through a $1 \%$ agarose gel and stained with ethidium bromide. The numbers 24 and 36 represent CMV-infected T. expansa grown at 24 and $36^{\circ} \mathrm{C}$, respectively. M: Mock-inoculated $T$. expansa grown at $24^{\circ} \mathrm{C}$. 
Experiments combining both detachment and temperature shift were carried out also. CMV-inoculated $T$. expansa plants in which inoculated leaves were detached and the plants moved from the chamber at $36^{\circ} \mathrm{C}$ to another chamber at $24^{\circ} \mathrm{C}$ at 24 hpi developed no systemic infection at $8 \mathrm{dpi}(0 / 15)$. However, more than half of the plants $(12 / 20)$ in which inoculated leaves were detached at $24 \mathrm{hpi}$ and the plants moved to the $24^{\circ} \mathrm{C}$ chamber at $36 \mathrm{hpi}$ exhibited systemic infection. All the plants $(25 / 25)$ in which inoculated leaves were detached at $24 \mathrm{hpi}$ and the plants kept in the chamber at $36^{\circ} \mathrm{C}$ showed systemic symptoms. These results indicated that some period of time after entering the phloem cells was required for CMV to establish systemic infection in T. expansa at $36^{\circ} \mathrm{C}$.

To support these findings, we traced, by RT-PCR, the CMV accumulation in the petioles of the inoculated leaves, the stems, and the petioles of the second upper leaves from plants grown at $36^{\circ} \mathrm{C}$ at $24,36,48$, and $72 \mathrm{hpi}$. CMV was detected in the petioles of the inoculated leaves and the stems but not in the petioles of the upper leaves at 24 hpi (Fig. 5, lane 24). However, the virus was identified in the petioles of the upper leaves at and after $36 \mathrm{hpi}$ (Fig. 5, lanes 36 to 72). This demonstrates that CMV moved from the stems into the petioles of the upper leaves between 24 and $36 \mathrm{hpi}$ at $36^{\circ} \mathrm{C}$.

Distribution of $\mathrm{CMV}$ in the petiole of inoculated leaves of plants grown at 24 or $36^{\circ} \mathrm{C}$. We further observed CMV distribution in the petioles of the inoculated leaves at $5 \mathrm{dpi}$ of plants grown at 24 or $36^{\circ} \mathrm{C}$ using immuno-histochemistry. Ten petioles each from plants grown at 24 or $36^{\circ} \mathrm{C}$ were analyzed. Vascular tissue from plants grown at $36^{\circ} \mathrm{C}$ was slightly larger than that at $24^{\circ} \mathrm{C}$. Signal was detected in the external phloem, the xylem parenchyma, and the internal phloem cells from plants grown at $36^{\circ} \mathrm{C}$ (Fig. 6A). In contrast, CMV was confined to a few cells of the external phloem from plants grown at $24^{\circ} \mathrm{C}$. CMV was never detected in xylem parenchyma cells and internal phloem cells from plants grown at $24^{\circ} \mathrm{C}$ (Fig. 6B). This strongly suggests that CMV did not move from the external phloem to the internal phloem at $24^{\circ} \mathrm{C}$.

\section{DISCUSSION}

Systemic resistance of $T$. expansa against CMV infection is temperature-sensitive. The host plant is systemically infected with

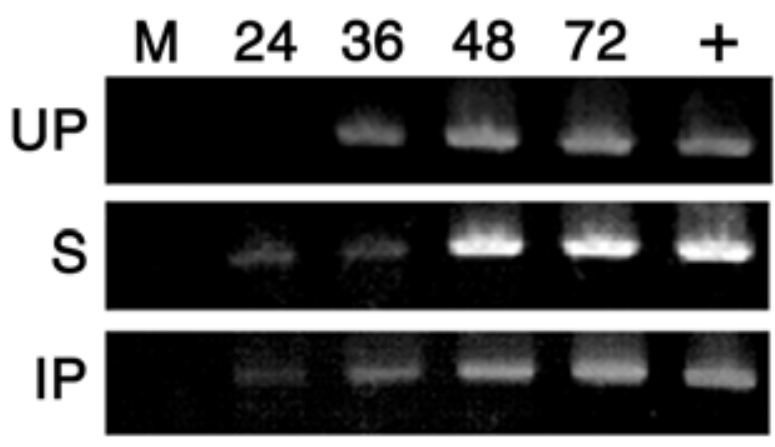

Fig. 5. Detection of Cucumber mosaic virus (CMV) in the petioles from inoculated leaves (IP), stem ( $\mathrm{S}$, internode between the inoculated and upper leaves), and the petioles from systemic leaves above the inoculated leaf (UP) of Tetragonia expansa. Tissue samples were taken at 24, 36, 48, and $72 \mathrm{~h}$ postinoculation (indicated by $24,36,48$, and 72 , respectively). The plants were incubated at $36^{\circ} \mathrm{C}$. Total RNA (500 ng) extracted from IP, S, or UP was reverse-transcribed using primers that would amplify the CMV coat protein gene fragment, which is approximately 500 bp long. Reverse transcriptionpolymerase chain reaction products were electrophoresed through a $1 \%$ agarose gel and stained with ethidium bromide. Mock-inoculation (M) and purified CMV RNA (+) were used as the controls.
A

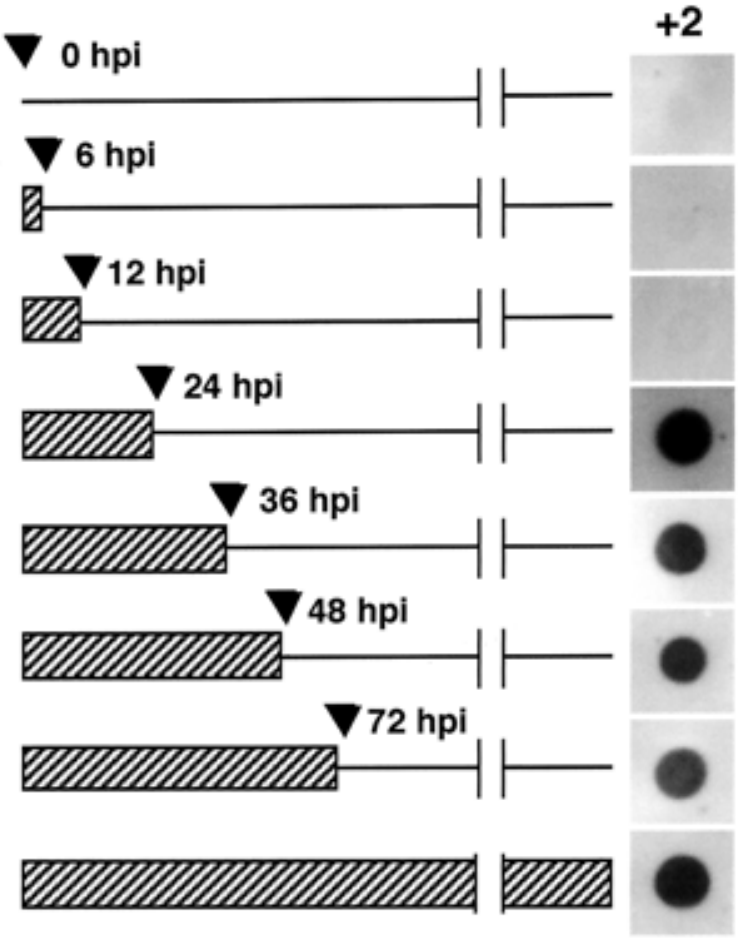

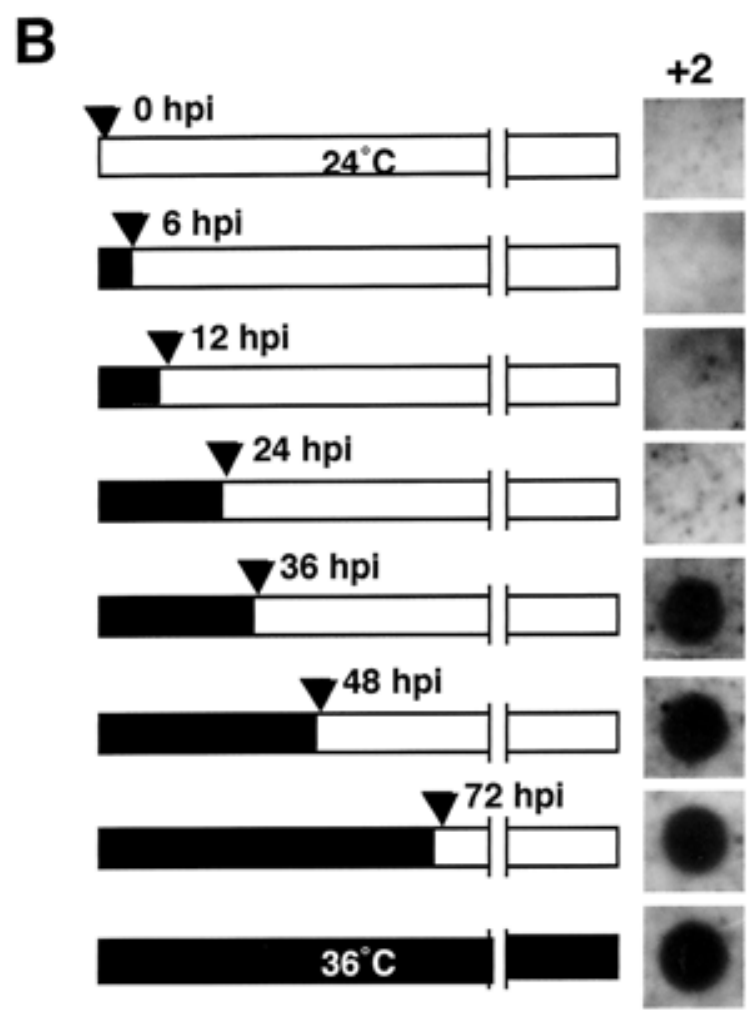

Fig. 4. Dot blot analysis of tissue from the second systemic leaves (+2) of Tetragonia expansa grown at $36^{\circ} \mathrm{C}$ from which A, Cucumber mosaic virus (CMV)inoculated leaves were detached at different times or B, CMV-inoculated T. expansa was moved from a $36^{\circ} \mathrm{C}$ growth condition to a $24^{\circ} \mathrm{C}$ growth condition for varying times. Total RNA extracted from the upper leaves at 8 days postinoculation was spotted onto nylon membrane and hybridized with the same RNA probe used in Figure 1. These panels show samples spotted on the same membrane. A, The inoculated leaves with petioles were cut from the stem at 0, 6, 12, $24,36,48$, and $72 \mathrm{~h}$ postinoculation (hpi). Arrowheads show the time that inoculated leaves were detached. $\mathbf{B}$, Plants incubated at $36^{\circ} \mathrm{C}$ were moved to the chamber at $24^{\circ} \mathrm{C}$ at $0,6,12,24,36,48$, and $72 \mathrm{hpi}$. Arrowheads indicate the time that plants were moved from the $36^{\circ} \mathrm{C}$ chamber to the $24^{\circ} \mathrm{C}$ chamber. 
CMV at growth treatment of $36^{\circ} \mathrm{C}$ or greater, whereas it is locally infected when grown at $24^{\circ} \mathrm{C}(19)$. In this study, we demonstrated that CMV entered the phloem cells of the inoculated leaf but did not accumulate in the petioles of the upper leaves at $24^{\circ} \mathrm{C}$ and that CMV requires a period at high temperature after entering the stem in order to establish a systemic infection.

Leaf press-blotting demonstrated that both the quantity and size of the infection sites in the inoculated leaves increased more rapidly at $36^{\circ} \mathrm{C}$ than at $24^{\circ} \mathrm{C}$ (Fig. 1). This result suggests that the high temperature conditions facilitated the cell-to-cell movement of CMV in the inoculated leaves of T. expansa. The efficiency of cell-to-cell movement often is related to that of vascular movement (26). However, the movement through plasmodesmata between mesophyll cells that was facilitated in plants grown at $36^{\circ} \mathrm{C}$ was not the cause of the systemic infection exhibited by only these plants because CMV also was detected in the phloem cells in the inoculated leaves at $24^{\circ} \mathrm{C}$ (Figs. 2 and 6; Table 1). The facilitation of cell-to-cell movement at $36^{\circ} \mathrm{C}$ in this study may, however, influence the establishment of systemic infection, because more virus particles may enter the phloem pathway in plants grown at $36^{\circ} \mathrm{C}$. It also might result in the lower percentage of infected cells observed among the phloem cells in the inoculated leaves from plants grown at $24^{\circ} \mathrm{C}$ compared with those grown at $36^{\circ} \mathrm{C}$ (Table 1 ).

Several groups reported the inhibition of systemic movement after entering in phloem $(6,11,12,15,25)$. In T. expansa, CMV was transported into the phloem in plants grown at either 24 or $36^{\circ} \mathrm{C}$ (Table 1; Fig. 2), indicating that systemic movement of CMV was inhibited after entering the phloem tissue in plants grown at $24^{\circ} \mathrm{C}$. CMV was transported into the petioles of the inoculated leaves

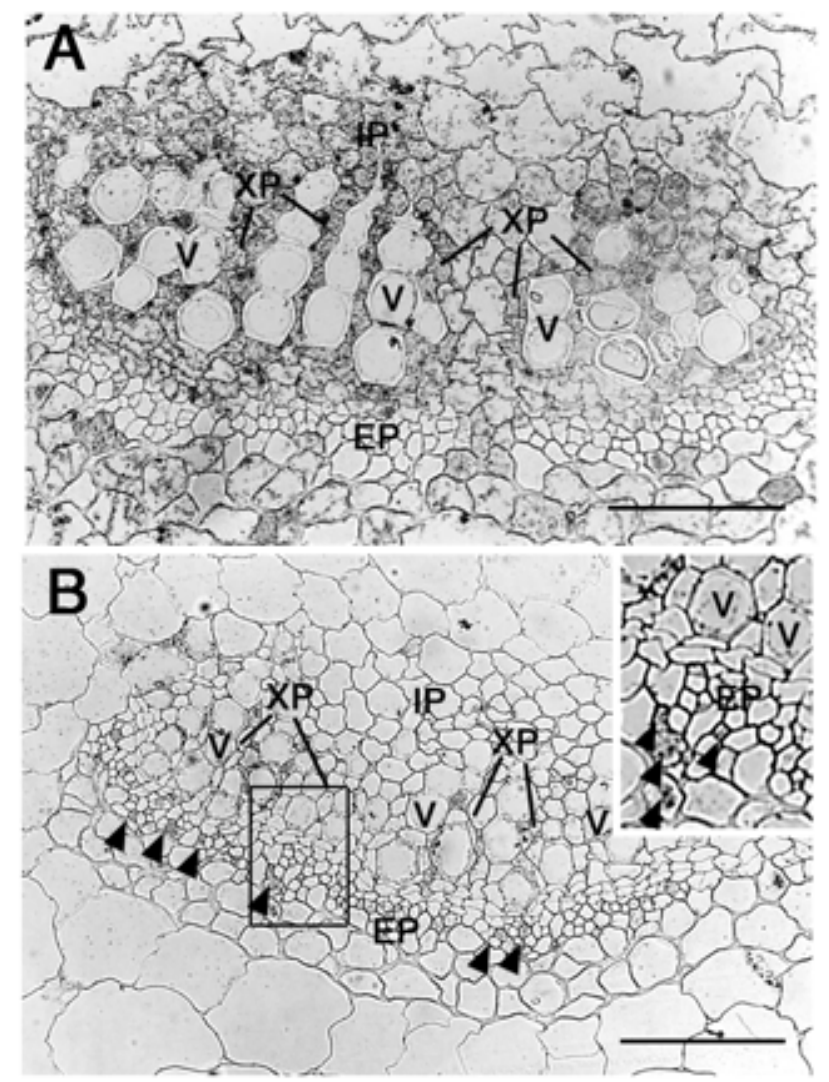

Fig. 6. Immuno-histochemical analysis of Cucumber mosaic virus (CMV) distribution in the petioles of inoculated leaves of Tetragonia expansa grown at $\mathbf{A}, 36^{\circ} \mathrm{C}$ and $\mathbf{B}, 24^{\circ} \mathrm{C}$. Phloem tissue in the petioles is labeled as external phloem (EP) or internal phloem (IP) on either side of the xylem. A, CMV was detected in EP, xylem parenchyma (XP), and IP at $36^{\circ} \mathrm{C}$, but $\mathbf{B}$, was only detected in limited cells in $\mathrm{EP}$ at $24^{\circ} \mathrm{C}$ (indicated by arrowheads). $\mathrm{V}$ : vessel. Bars $=50 \mu \mathrm{m}$. and the stem but not into the petioles of the upper leaves in plants grown at $24^{\circ} \mathrm{C}$ (Fig. 3). It is of interest that CMV is transported from the petioles of the inoculated leaves to the stem but not from the stem to the petioles of the upper leaves in plants grown at $24^{\circ} \mathrm{C}$.

The transportation pathway of viruses from petioles to stems is presumably different from that of stems to petioles. The phloem in the major veins of leaves, petioles, and stems is divided into external and internal phloem in some plant families including Aizoaceae. This structural differentiation has functional consequences for the photoassimilate transport (33). The external phloem is used for phloem loading and the internal phloem is used for phloem unloading to uninfected leaves in PepMoV-C. annиит and TMV-N. benthamiana systems $(1,5)$. In this study, CMV was detected only in the external phloem in plants grown at $24^{\circ} \mathrm{C}$, but was in both the external and the internal phloem in plants grown at $36^{\circ} \mathrm{C}$ (Fig. 6). These findings suggest that the inhibition of systemic infection by CMV in T. expansa grown at $24^{\circ} \mathrm{C}$ is due to the inhibition of viral transport between the external and the internal phloem within the veinal cells. Andrianifahanana et al. (1) and Cheng et al. (5) reported that the viruses they studied may have been transported from external to internal phloem in the stem at or below the inoculated leaves. Although the specific sites inhibiting CMV movement in $T$. expansa grown at $24^{\circ} \mathrm{C}$ have not yet been identified, CMV appears to be transported from the external to the internal phloem through the xylem parenchyma at least in the petioles of the inoculated leaves of plants grown at $36^{\circ} \mathrm{C}$ (Fig. 6). First- to third-order veins have both external and internal phloem, but minor veins have only external phloem in T. expansa. The virus cannot move from external phloem to internal phloem in leaf blade of the inoculated leaf except in major veins. Viral transportation from the external to the internal phloem could have occurred in the major veins and petiole of the inoculated leaf as well as in the stem.

Plant growth under high temperature conditions from 24 to 36 hpi was required for CMV to establish systemic infection (Fig. 4). Furthermore, CMV was transported from the stem into the petioles of the upper leaves at 24 to $36 \mathrm{hpi}$ in plants grown at $36^{\circ} \mathrm{C}$ (Fig. 5). These findings confirm that there is another barrier against CMV movement after viral entry into the phloem pathway. The barrier is probably at the interface between the external and the internal phloem, as discussed previously. It should be noted that CMV was detected in the petiole of the inoculated leaf by 24 hpi but not in the petiole of the upper leaf until 36 hpi (Fig. 4), in spite of the observation that long-distance movement of plant viruses occurs at a rate in the centimeter per hour range (16). The additional $12 \mathrm{~h}$ necessary for CMV accumulation in the upper leaf petiole might be required for CMV to move cell-to-cell from the external to the internal phloem through major vein or stem xylem parenchyma cells at $36^{\circ} \mathrm{C}$. CMV signals were detected not only in the external and the internal phloem but also in the xylem parenchyma cells at $36^{\circ} \mathrm{C}$ (Fig. 6). Cell-to-cell movement occurs at the rate of micrometer per hour (16), and this rate of movement is compatible with the extended time required for accumulation in the upper petioles. Increasing temperature should affect viral movement in the interface of external phloem-xylem parenchyma rather than that of xylem parenchyma-xylem parenchyma or xylem parenchyma-internal phloem, because the CMV in the petioles of the inoculated leaves was localized only in the external phloem at $24^{\circ} \mathrm{C}$ (Fig. 6).

There are other factors that may affect the systemic accumulation of CMV in T. expansa. One is the altered development and growth of vascular tissues in plants grown at $36^{\circ} \mathrm{C}$ versus $24^{\circ} \mathrm{C}$ (Fig. 6). The second is the potential inhibition of unloading of virus from the external phloem into the surrounding cells that may be due to a physical barrier such as callose deposition $(17,35)$.

From these results, we conclude that the movement of pepoCMV is inhibited after entry into the phloem at $24^{\circ} \mathrm{C}$ in $T$. ex- 
pansa, which may be caused by the inhibition of viral transport from external to internal phloem. These results should provide important insight into further exploration of not only the temperature-sensitive resistance mechanisms of $T$. expansa against CMV infection but also the tracking of plant viruses in systemic infections. CMV strains that overcome the inhibition at $24^{\circ} \mathrm{C}$ would provide further information into viral-host mutuality.

\section{LITERATURE CITED}

1. Andrianifahanana, M., Lovins, K., Dute, R., Sikora, E., and Murphy, J. F. 1997. Pathway for phloem-dependent movement of pepper mottle potyvirus in the stem of Capsicum annuum. Phytopathology 87:892898.

2. Boccard, F., and Baulcombe, D. 1993. Mutational analysis of cis-acting sequences and gene function in RNA3 of cucumber mosaic virus. Virology 193:563-578.

3. Canto, T., Prior, D. A. M., Hellwald, K. H., Oparka, K. J., and Palukaitis, P. 1997. Characterization of cucumber mosaic virus. IV. Movement protein and coat protein are both essential for cell-to-cell movement of cucumber mosaic virus. Virology 237:237-248.

4. Carrington, J. C., Kasschau, K. D., Mahajan, S. K., and Schaad, M. C. 1996. Cell-to-cell and long-distance transport of viruses in plants. Plant Cell 8:1669-1681.

5. Cheng, N.-H., Su, C.-L., Carter, S. A., and Nelson, R. S. 2000. Vascular invasion routes and systemic accumulation patterns of tobacco mosaic virus in Nicotiana benthamiana. Plant J. 23:349-362.

6. Citovsky, V., Ghoshroy, S., Tsui, F., and Klessig, D. 1998. Non-toxic concentrations of cadmium inhibit systemic movement of turnip vein clearing virus by a salicylic acid-independent mechanism. Plant J. 16:1320.

7. Ding, B., Li, Q., Nguyen, L., Palukaitis, P., and Lucas, W. J. 1995. Cucumber mosaic virus 3a potentiates cell-to-cell trafficking of CMV RNA in tobacco plants. Virology 207:345-353.

8. Ding, B., Parthasarathy, M. V., Niklas, K., and Turgeon, R. 1988. A morphometric analysis of the phloem-unloading pathway in developing tobacco leaves. Planta 176:307-318.

9. Ding, S.-W., Li, W.-X., and Symons, R. H. 1995. A novel naturally occurring hybrid gene encoded by a plant RNA virus facilitates longdistance virus movement. EMBO J. 14:5762-5772.

10. Ding, X. S., Shintaku, M. H., Carter, S. A., Nelson, R. S. 1996. Invasion of minor veins of tobacco leaves inoculated with Tobacco mosaic virus mutants defective in phloem-dependent movement. Proc. Natl. Acad. Sci. USA 93:11155-11160.

11. Dufour, O., Palloix, A., Selassie, K. G., Pochard, E., and Marchoux, G. 1989. The distribution of cucumber mosaic virus resistant and susceptible plants of pepper. Can. J. Bot. 67:655-660.

12. García-Castillo, S., Marcos, J. F., Pallás, V., and Sánchez-Pina, M. A. 2001. Influence of the plant growing conditions on the translocation routes and systemic infection of carnation mottle virus in Chenopodium quinoa plants. Physiol. Mol. Plant Pathol. 58:229-238.

13. Gilbertson, R. L., and Lucas, W. J. 1996. How do viruses traffic on the 'vascular highway'? Trends Plant Sci. 1:260-268.

14. Goodrick, B. J., Kuhn, C. W., and Hussey, R. S. 1991. Restricted systemic movement of cowpea chlorotic mottle virus in soybean with nonnecrotic resistance. Phytopathology 81:1426-1431.

15. Guerini, M. N., and Murphy, J. F. 1999. Resistance of Capsicum annuum 'Avelar' to pepper mottle potyvirus and alleviation of this resistance by co-infection with cucumber mosaic cucumovirus are associated with virus movement. J. Gen. Virol. 80:2785-2792.

16. Hull, R. 2002. Induction of disease 1: Virus movement through the plant and effects on plant metabolism. Pages 373-436 in: Matthew's Plant Virology. Academic Press, San Diego.

17. Iglesias, V. A., and Meins, F. 2000. Movement of plant viruses is delayed in a $\beta$-1,3-glucanase-deficient mutant showing a reduced plasmodesmatal size exclusion limit and enhanced callose deposition. Plant J. 21:157-166.
18. Kaplan, I. B., Gal-On, A., and Palukaitis, P. 1997. Characterization of cucumber mosaic virus. III. Localization of sequences in the movement protein controlling systemic infection in cucurbits. Virology 230:343349 .

19. Kobori, T., Miyagawa, M., Nishioka, K., Ohki, S. T., and Osaki, T. 2002. Amino acid 129 of Cucumber mosaic virus coat protein determines local symptom expression and systemic movement in Tetragonia expansa, Momordica charantia and Physalis floridana. J. Gen. Plant Pathol. 68:81-88.

20. Kobori, T., Ohki, S. T., and Osaki, T. 2000. Movement of Cucumber mosaic virus is restricted at the interface between mesophyll and phloem pathway in Cucumis figarei. J. Gen. Plant Pathol. 66:159-166.

21. Lucas, W. J., and Gilbertson, R. L. 1994. Plasmodesmata in relation to viral movement within leaf tissues. Annu. Rev. Phytopathol. 32:387-411.

22. Nelson, R. S., and van Bel, A. J. E. 1998. The mystery of virus trafficking into, through and out of the vascular tissues. Prog. Bot. 59:476-533.

23. Saiga, T., Fujiwara, M., Saitoh, H., Ohki, S. T., and Osaki, T. 1998. Comparative analysis for replication and movement of cucumber mosaic virus in Cucumis figarei and C. melo. Ann. Phytopathol. Soc. Jpn. 64: 255-263.

24. Saitoh, H., Saiga, T., Ohki, S. T., and Osaki, T. 1998. Systemic resistance in Cucumis figarei to some strains of cucumber mosaic virus is breakable at high temperature. Ann. Phytopathol. Soc. Jpn. 64:194-197.

25. Schaad, M. C., and Carrington, J. C. 1996. Suppression of long-distance movement of tobacco etch virus in a nonsusceptible host. J. Virol. 70:2556-2561.

26. Séron, K., and Haenni, A. L. 1996. Vascular movement of plant viruses. Mol. Plant-Microbe Interact. 9:435-442.

27. Soards, A. J., Murphy, A. M., Palukaitis, P., and Carr, J. P. 2002. Virulence and differential local and systemic spread of Cucumber mosaic virus in tobacco are affected by the CMV 2b protein. Mol. PlantMicrobe Interact. 15:647-653.

28. Suzuki, M., Kuwata, S., Kataoka, J., Masuta, C., Nitta, N., and Takanami, Y. 1991. Functional analysis of deletion mutants of cucumber mosaic virus RNA3 using an in vitro transcription system. Virology 183:106-113.

29. Szilassy, D., Salánki, K., and Balázs, E. 1999. Stunting induced by cucumber mosaic cucumovirus-infected Nicotiana glutinosa is determined by a single amino acid residue in the coat protein. Mol. PlantMicrobe Interact. 12:1105-1113.

30. Takanami, Y. 1981. A striking change in symptoms on cucumber mosaic virus-infected tobacco plants induced by satellite RNA. Virology 109:120-126.

31. Taliansky, M. E., and García-Arenal, F. 1995. Role of cucumovirus capsid protein in long-distance movement within the infected plant. J. Virol. 69:916-922.

32. Thompson, J. R., and García-Arenal, F. 1998. The bundle sheath-phloem interface of Cucumis sativus is a boundary to systemic infection by tomato aspermy virus. Mol. Plant-Microbe Interact. 11:109-114.

33. Turgeon, R. 1989. The sink-source transition in leaves. Annu. Rev. Plant Physiol. Plant Mol. Biol. 40:119-138.

34. Uchiba, T., Shigemune, N., Yoshitugu, M., Takeshita, M., and Takanami, Y. 2001. Subgroup-specific detection of Cucumber mosaic virus RNA in tobacco leaves by tissue-printing. J. Fac. Agric. Kyusyu Univ. 45:437441.

35. Ueki, S., and Citovsky, V. 2002. The systemic movement of a tobamovirus is inhibited by a cadmium-ion-induced glycine-rich protein. Nat. Cell Biol. 4:478-486.

36. van Lent, J. W., and Verduin, B. J. M. 1987. Detection of viral antigen in semi-thin sections of plant tissue by immunogold-silver staining and light microscopy. Neth. J. Plant Pathol. 93:261-272.

37. Vaquero, C., Turner, A. P., Demangeat, G., Sanz, A., Serra, M. T., Roberts, K., and García-Luque, I. 1994. The 3a protein from cucumber mosaic virus increases the gating capacity of plasmodesmata in transgenic tobacco plants. J. Gen. Virol. 75:3193-3197.

38. Wintermantel, W. M., Banerjee, N., Oliver, J. C., Paolillo, D. J., and Zaitlin, M. 1997. Cucumber mosaic virus is restricted from entering minor veins in transgenic tobacco exhibiting replicase-mediated resistance. Virology 231:248-257. 